\title{
The Effect of Ad Content and Ad Length on Consumer Response towards Online Video Advertisement
}

\author{
Djoko Raditya ${ }^{1}$; Willy Gunadi²; Dennis Andariski Setiono ${ }^{3 *}$; Jonathan Andreas Rawung ${ }^{4}$ \\ 1,2,3 Management Department, BINUS Business School Undergraduate Program, Bina Nusantara University \\ Jl. Kebon Jeruk Raya No. 27, Kebon Jeruk, Jakarta 11530, Indonesia \\ ${ }^{4}$ PT Blue Power Technology, Jakarta, Indonesia \\ Centennial Tower $12^{\text {th }}$ Floor, Jl. Gatot Subroto Jl. Peltu Rahmat Sidup No. Kav. 24 - 25, \\ Semanggi, Jakarta Selatan 12930, Indonesia

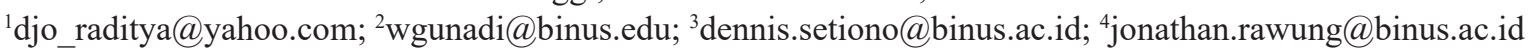

Received: $13^{\text {th }}$ November 2020/ Revised: $27^{\text {th }}$ November 2020/ Accepted: $08^{\text {th }}$ December 2020

\begin{abstract}
How to Cite: Raditya, D., Gunadi, W., Setiono, D. A., \& Rawung, J. A. (2020). The effect of ad content and ad length on consumer response towards online video advertisement. The Winners, 21(2), 119-128.
\end{abstract}

https://doi.org/10.21512/tw.v21i2.6797

\begin{abstract}
The research aimed to determine the moderating effect of advertisement (ad) length on the relationships between ad content and the intention of skipping, as well as ad irritation. The research attempted to fill in the lacuna in the academic literature on the said issue. In doing so, it examined consumers' responses towards the consumers' intention of adskipping and irritation. The experimental research utilized four video ads with varying durations and containing both entertaining and boring content, with long and short ad length. The research sample comprised 120 respondents spend at least more than 1 hour online. The research employed convenience sampling and the method of Univariate Analysis of Variance Linear Model. IBM SPSS Statistics was used for data analysis. The results reveal that the content and length of an online video ad have a direct effect on consumers' ad irritation and intention of skipping. The research concludes that the perceived entertainment of an online video ad significantly affects consumers' intention of skipping and ad irritation. Furthermore, the length of video ads has a major impact on their intention of skipping and ad irritation.
\end{abstract}

Keywords: ad content, ad length, consumer response, online video advertisement

\section{INTRODUCTION}

Ever since the introduction of the broadband internet and the widespread use of smartphones worldwide, especially during the mid-2010s, the number of internet users has soared. According to statista.com, as of October 2019, there were a total of 4,536 million internet users, an increase of $8 \%$ from 2018 to 2019. The number is expected to grow even higher with the current trend of global tech companies, such as Google, which has expanded their sphere of influence worldwide. One of the most common online activities is video viewing from such websites as YouTube. Purposes for this activity vary, ranging from entertainment to education. Anderson (2018) argues that watching videos on YouTube helps relieve stress or escape from stressful day-to-day activities. However, being exposed to too many ads cause irritation towards the ad (Zhou \& Xue, 2019). Video platforms, such as Youtube, has created a method to reduce the ad irritation caused by providing the option to skip the video ad to hopefully reduce their irritation towards the video-sharing site and purchase intentions (Belanche, Flavián \& Pérez-Rueda, 2017). On the other hand, irritated viewers are more likely to avoid these video ads by clicking on the skip-ad button. A recent research based on a nationally representative sample finds that about two-thirds of viewers skip in-stream commercials. Those who skip the ads are less likely to recall the brand or engage in search of advertising-related terms (Manatt, 2017; Pashkevich et al., 2012). Previous research have examined the effectiveness of an online video ad is on a video sharing platform. However, only a few research have pinpointed the factors to why viewers skip online video ads and lead to ad irritation. The research analyzes the effects of ad content on a consumer's ad irritation and intention of skipping ads when moderated by ad duration. The research helps the marketer adapt their video ad to be more favorable towards consumers. Furthermore, Ducoffe (1996) supports this by saying 
that the attitude a consumer gives towards an ad is also affected by the entertainment and irritation value of the advertisement. This affects a consumer's intention towards the ad itself, which is a factor in consumer behavior and their response towards the ad.

Ducoffe (1996) develops three distinct factors that influence a viewer's attitudes towards online video ads. It proves that viewers' attitude towards an advertisement is determined by their perception of entertainment, informativeness, and irritation towards it. Informativeness is usually defined as the advertising's ability to give viewers information about alternative product options (Ducoffe, 1996). Scholars use these factors to identify how effective an advertising model is on various platforms, such as Facebook, for hotel reservations (Hamouda, 2018), Twitter (Murillo, Merino \& Núñez, 2016), YouTube (Yang et al., 2018), search engine (Murillo, 2017), and others. It can be concluded that any uninteresting advertisement will be seen as irritating by consumers. Ducoffe (1996) mentions that entertainment triggers positive emotions for consumers when they watch an ad. Tsai and Men (2017) has found the entertainment value to be a factor to promote engagement of an advertisement with consumers. Entertainment attributes have a positive effect on the creation of advertising value (Hamouda, 2018; Núñez-Barriopedro et al., 2019). Advertising needs to entertain its consumers as it is believed that it can increase the effectiveness of the message as it can help catch consumers' attention (Goodrich et al., 2015) and generate a positive attitude of the viewers (Puwandi, 2019).

There has been plenty of research regarding the correlation between the length of an ad and its effects. However, only a few have tackled the correlation between the length of an ad and its content (Song et al., 2020; "MRC cross-media", 2020). The most effective ad duration comprises six-seconds (Fleck, 2018). Jones (2016) finds that fifteen-second ads lead to the highest level of brand recall compared to thirty-second and longer ads. This is proven true as $40 \%$ of all online video ads have a fifteen-second duration, making it the most common video ad format(Krizelman, 2019). Short ads, which last around 6 seconds, are also preferred by brands as they realize that long ads are bothering customers in general. Also, customers' tolerance for these long ads is getting shorter and shorter each passing day ("Why you should be", 2017), resulting in these ads being perceived negatively (Herhold, 2018). However, consumers also feel annoyed towards ads that are too short (Goodrich et al., 2015). Based on these findings, consumers poorly receive thirty-second mandatory ads called "pre-roll" ads with regards to purchasing intention. Instead, it can be assumed that it will cause irritation and a higher intention to skip, as today's viewers are likely to find ads with a length of 30 seconds or longer to be too long for an online video ad (Wasserman, 2020). Even though ads that last for too long are received negatively by consumers, when the main purpose or objective of the ad is to persuade consumers or to attract consumers to their brand, then ads that last longer are much more effective to deliver the message ( $\mathrm{Li}$ and Lo, 2015). On the other hand, the perceived length of an ad may be subjective to different viewers (Gesenhues, 2014); thus, figuring the ideal length for a video ad may prove challenging. Campbell et al. (2017) find that consumers tend to find pre-roll ads or online video ads that play before their chosen video content to be much more intrusive than regular online video ads. This can perfectly describe the feeling of advertising intrusiveness, which negatively affects consumers' attitudes and intentions (McCoy et al., 2017; Redondo et al., 2018; Park et al., 2019) and lead to ad avoidance (Chung, 2020). Hence, intrusiveness in an ad can have a strong impact on marketing outcomes for marketers. As the length of an ad increases, waiting time will be longer, and thus perceived intrusiveness and irritation should rise as well.

Entertaining itself can be defined as being funny and enjoyable. It is an important factor in regard to an ad regardless of its form, as it can affect the perceptions of the value the advertising has (Hamouda, 2018) and further supported by Mahatmavidya and Yasa (2020) that entertainment is an important factor when customers see ads. When an ad has a very high entertainment content, is very humorous, and can find a relatable way of delivering the advertisement to the customers, it is much easier for consumers to understand and enjoy it (Giao and Vuong, 2020; Dehghani, 2016). This also lures consumers, as with the help of entertainment, they can feel enjoyment and fulfill their needs for enjoyment, emotional release, as well as a pleasure to experience the stories as unforgettable ones. It is mainly because consumers usually expect to see interesting and entertaining values from these ads, which normally involves a unique execution (such as its interactivity, appeals, and experience) on how they deliver the ad (Zhang and Mao, 2016). Nevertheless, this kind of ad will mesmerize and retain the consumer's attention, encourage involvement, and take the stories in the ad with them. A previous research shows that entertaining ads are found to provide enjoyment and fun (Shareef et al., 2018). By reversing this logic, it is assumed that the ads that are neither entertaining nor boring will make consumers feel irritated. The relationship between ad content and ad irritation appears strongest when the ad length is long. In contrast, the ad irritation appears lowest when the ad length is short. Ad length thus has a moderating effect on ad irritation.

The feeling of annoyance and irritation tends to happen when consumers feel that they have less control and freedom over the choices that they can make or have (Amarnath \& Jaidev, 2020). This is true regarding online advertising that appears on video streaming websites and other social platforms. Ducoffe (1996) states that consumers will be irritated with ads when it is perceived as annoying, offensive, or manipulative. As such, the perceived intrusiveness of an online video ad will cause consumers to feel irritated towards them. Several research in the past also have found 
issues related to advertising irritation (Kim, 2018; Jeon et al., 2019; Youn and Shin, 2019; Kempers, 2020). One of the many reasons for the occurrence of ad irritation is related to the characteristics of native advertising, which is a form of ad that matches the form and function of the platform it appears in (Youn and Kim, 2019). These kinds of ads have proven to create a strong negative perception from consumers, such as feelings of obstruction, restrain, irritation, and cluttering, which leads to the consumers wanting to avoid these ads even more. Although the perceived irritation from advertising may differ from everyone, some individuals may not consider ads that are irritating to others to be irritating as it still makes sense to them not to consider it ridiculous, much more irritating (Warren, Barsky \& McGraw, 2018). Cho (2004) supports this fact by pointing out that irritated viewers are highly likely to avoid commercials by clicking the skip-ad button. Seyedghorban et al. (2016) also found that when a consumer is faced with obstructions to their goals, has bad experiences towards ads, and perceived ad clutter will lead to ad avoidance on the internet customer's cognitive, affective, and behaviors towards it. Multiple research have studied advertising avoidance both in a traditional media environment and the online media environment (Huh et al., 2015; Vohra and Bhardwaj, 2019). One of the many reasons that consumers avoid an ad is when they feel that the advertising is not relevant to them ( $\mathrm{Li}$ and Huang, 2016) or when the advertising is perceived as being obstructive (Jung et al., 2016). Other research have suggested that the negative perception the ads received from users stems from the belief that these users feel their privacy on the internet is gone. The consumers believed that they are being targeted and tracked by these ads when they encounter an ad without their consent (Lee and Hong, 2016). Therefore, consumers will avoid advertising whenever possible (Dodoo \& Wen, 2019).

A survey at Statista also shows that $32 \%$ of the U.S. total consumers agreed that video ads on YouTube are very annoying ("Share of consumers", 2019). This could explain the consumers' feeling of ad irritation and the high intention of skipping ads. They will do anything to avoid the video ad, which is stopping them from reaching their goal. Concerning this, ads that cannot be skipped regardless of duration are the most hated type of video ads (Willner, 2018), as it can generally be agreed that no customer would like to wait (Hardisty \& Weber, 2020). However, it can be assumed that the perceived entertainment value of an ad will highly affect a customer's attitude and intention of skipping ads when they find it entertaining, regardless of the length of the ad.

A delay to a consumer's desired content can be perceived as anticipation. When a consumer is anticipating a future positive outcome, it can be called savoring (Chun et al., 2017). However, when a negative feeling is perceived while consumers are anticipating a positive outcome (e.g., seeing an online video ad before watching a chosen content), it is called impatience. As such, it can be considered that the intention to skip ad and ad irritation comes from a consumer's impatience to view their chosen content. As the length of an ad increases, the waiting time will increase. Thus, perceived intrusiveness and irritation should also increase. With the increase of ad irritation, people will likely have more intention to skip the ads. This leads to viewers clicking on the "skip-ad button" as a form of "avoidance" or "escaping" the source of irritation (Campbell et al., 2017). Benes (2018) also supports this as $65 \%$ to $90 \%$ of consumers will skip video ads as soon as the option to do so is available.

Petrovici (2017) finds that consumers always perceive ads on the internet to be disruptive and considered to be an obstacle. The ads disrupt them from enjoying their chosen content, and this is further supported by a survey on YouTube, Google's videosharing platform. The survey shows that the biggest complaint on Youtube content is the in-stream commercials (Pashkevich et al., 2012). Depending on the consumer's perception, video advertising that lasts for more than 15 seconds is irritating and is deemed too long, while those that last for 15 seconds or less are more acceptable and less irritable (Gesenhues, 2014). As stated previously, the entertainment value of an ad will make it much more enjoyable to watch, thus leading to a lower intention of skipping ads even when the length of the ad is deemed to be extended. This creates a relationship between ad content, and the intention of skipping ads becomes strongest when the ad length is long. Therefore, when the length of the video ad is perceived to be short, consumers will feel less irritated and thus have less intention to skip the ad. Based on the previous research, it can be hypothesized that the length and content of an ad can affect the intention of skipping ads and the irritation of a viewer towards it.

\section{METHODS}

Hypotheses are tested through an experiment utilizing actual scenarios to see if the hypotheses are true. A website is prepared to accommodate a real video streaming experience similar to YouTube and four ad videos with varying criteria.

Several manipulation checks surveys are conducted prior to the main experiment to ensure the participant perceived, comprehend, and reacted as expected of interest contained within the independent variable (Hoewe, 2017). Four separate manipulation checks are prepared, each with the four variables in them, to ensure that there is no comparison and bias from the participants. Each manipulation check is distributed to different individuals without overlapping the different manipulation checks. 40 participants are gathered to proceed with the manipulation checks. The manipulation checks and the main experiment are conducted in a video streaming website similar to YouTube. The manipulation checks were conducted from May $11^{\text {th }}, 2020$ to May $13^{\text {th }}, 2020$, and then 
the main experiment was proceeded from May $14^{\text {th }}$, 2020 until May $16^{\text {th }}$, 2020. Using a convenience sampling method, the experiment and survey are conducted online using a Google survey to determine the participants' behavior and preference regarding online video ads. The link to this survey is posted on our social media. These individuals are eligible if they use the internet regularly or spend at least one hour browsing the internet daily. According to Cohen et al. (2007), experimental methodologies require at least 15 participants. However, 30 respondents are tested for each condition. A factorial design is used with two independent variables and two dependent variables, creating a $2 \times 2$ between the subject. Therefore, a total of 120 participants is gathered for this experiment. The data are analyzed with SPSS using Univariate Analysis.

The research aims to prove and show the importance of the relationship between ad content in an online video ad with the intention of skipping ads and ad irritation of the consumers. The research model is presented in Figure 1. The questions used to determine the measurement of irritation are adopted from a 5-item scale of perceived irritation ( $\mathrm{Li}$, Edwards $\&$ Lee, 2002). Participants agree that the ad that they watched is: (1) irritating, (2) phony, (3) ridiculous, (4) stupid, or (5) terrible, on a 5-point scale anchored by "Strongly disagree" (=1) and "Strongly agree" (=5). In measuring the intention of skipping ads, the research adapts the measurement from Shehu et al. (2016).

The duration and content of an ad affect viewer's intention of skipping ads and ad irritation. Thus, the hypothesis of this experiment is:

$\mathrm{H}_{1}$ : When an ad content is boring, consumers will be more irritated if the ad length is long compared to the shorter ad length.

$\mathrm{H}_{2}$ : When an ad content is boring, consumers will more likely have a higher intention of skipping ads if the ad length is long compared to the shorter ad length.

The criteria have two categories, ad content (entertaining and boring) and ad length (short and long). To support this purpose, manipulation checks have previously conducted to determine our hypothesized criteria. Four different video ads have been collected to support four criteria, in which boring ads are ad videos with awful and unclear humor. In contrast, entertaining ads are ad videos with funny or catchy humor. Two ad lengths are also considered the short and long ones. Furthermore, video ad can be detailed as provided:

Video 1:

Criteria: Entertaining and long

Title: McDonald's 2011 Straws Commercial 30 Seconds

URL: $\quad$ https://www.youtube.com/ watch? $\mathrm{v}=\mathrm{X} 18 \mathrm{o} 6 \mathrm{FkNuSc}$

Video 2:

Criteria: Boring and long

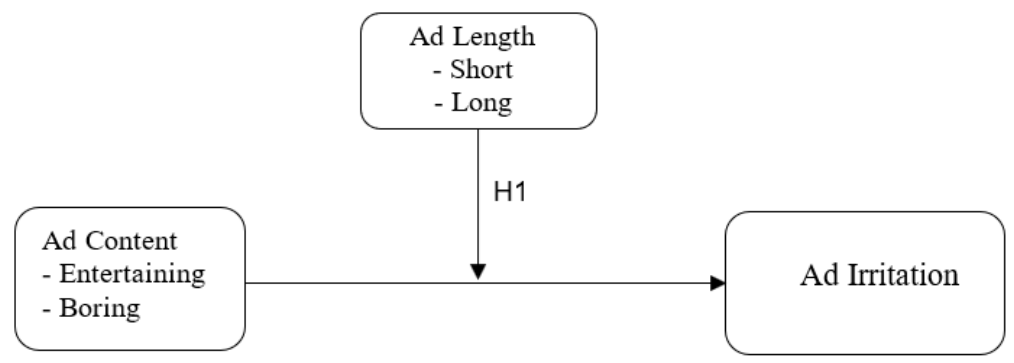

(a)

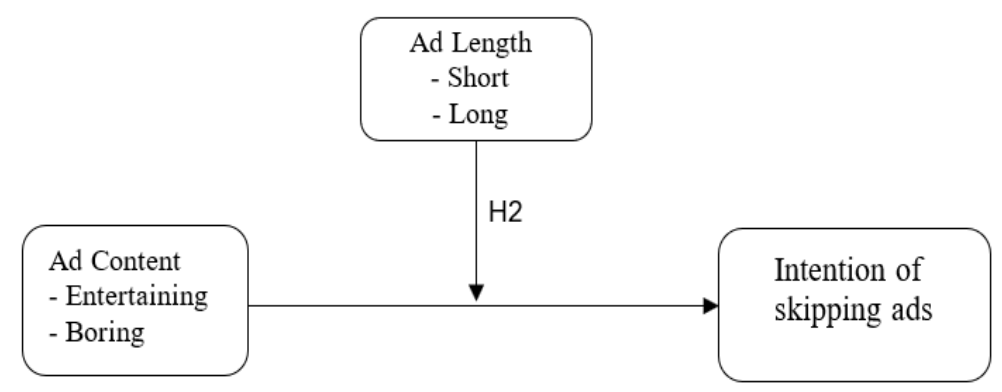

(b)

Notes: (a) Experiment 1; (b) Experiment 2

Figure 1 Research Model 
Title: Iklan Tecstar 30 detik.mpg

URL: https://www.youtube.com/ watch? $\mathrm{v}=\mathrm{oBtRb} 5 \mathrm{cSw} 1 \mathrm{c}$

Video 3:

Criteria: Entertaining and short Title: [ILM 2019] e-filing 15 detik

URL: https://www.youtube.com/ watch? $\mathrm{v}=\mathrm{WnCPDbyHpjE}$

Video 4:

Criteria: Boring and short

Title: Pepsi Max TV Commercial, "15 Seconds" URL: watch?v=JfJa8GXX1R4 https://www.youtube.com/

As a result of the manipulation checks, four different video ads are the same perception and will be used for the main testing. The prepared website will act similarly to YouTube with videos which attracts viewers. Participants can access the videos through a direct link to a video, which will direct them to the ads. After each session, there will be questionnaires that they have to fill and answer about the details of their experience and their irritation about the ads, if any. To ensure that each condition receives the same number of respondents, the number of respondents is monitored to a certain threshold. After each condition has met its required number of samples, the condition will be adjusted and changed to another video ad. Each respondent are collected by sharing them a link to the experiment website and questionnaires on social media, such as Facebook and Instagram.

\section{RESULTS AND DISCUSSIONS}

The criteria used for this research's demographic information include gender, age, occupation, and educational level. While the psychological information is gathered, the observation also covers the time they spent online and whether they use AdBlock. The gathered data are provided in Table 1, which also includes the frequency and percentage of the responses. The majority of the respondents are $71,1 \%$ male, $54,5 \%$ of the respondents are under 24 years old, with $24,8 \%$ of their latest education level being bachelors. The age range of respondents may result from how accessible the internet is now due to the widespread use of technology, such as smartphones. The highest occupation among the respondents is employees at $39,7 \%$ and students at $31,4 \%$, which may have stemmed from the fact that many employees and students work and study very closely to their computers and gadgets, allowing them to have more time surfing the internet or watching online videos compared to entrepreneurs and other jobs. The fact that $71,1 \%$ of them spend more than three hours on the internet supports this result.
Table 1 Respondents Profile

\begin{tabular}{|c|c|c|c|}
\hline Variable & Description & Frequency & $\begin{array}{c}\text { Percentage } \\
(\%)\end{array}$ \\
\hline \multirow[t]{2}{*}{ Gender } & Male & 86 & $71,1 \%$ \\
\hline & Female & 35 & $28,9 \%$ \\
\hline \multirow[t]{4}{*}{ Age } & $<24$ y.o. & 66 & $54,5 \%$ \\
\hline & $25-42$ у.о. & 55 & $45,5 \%$ \\
\hline & 43-55 у.о. & 0 & $0,0 \%$ \\
\hline & $>56$ у.о. & 0 & $0,0 \%$ \\
\hline \multirow[t]{6}{*}{$\begin{array}{l}\text { Education } \\
\text { Level }\end{array}$} & $\begin{array}{l}\text { Middle } \\
\text { School }\end{array}$ & 5 & $4,1 \%$ \\
\hline & High School & 30 & $24,8 \%$ \\
\hline & Diploma & 1 & $0,8 \%$ \\
\hline & Bachelor & 78 & $64,5 \%$ \\
\hline & Masters & 7 & $5,8 \%$ \\
\hline & Doctorate & 0 & $0,0 \%$ \\
\hline \multirow[t]{4}{*}{ Occupation } & Student & 38 & $31,4 \%$ \\
\hline & Employee & 48 & $39,7 \%$ \\
\hline & $\begin{array}{l}\text { Entrepre- } \\
\text { neur }\end{array}$ & 18 & $14,9 \%$ \\
\hline & Other & 17 & $14,0 \%$ \\
\hline \multirow{3}{*}{$\begin{array}{l}\text { Time spent } \\
\text { online/day }\end{array}$} & $<1$ hour & 5 & $4,1 \%$ \\
\hline & $1-3$ hours & 30 & $24,8 \%$ \\
\hline & $>3$ hours & 86 & $71,1 \%$ \\
\hline \multirow{2}{*}{$\begin{array}{l}\text { Do you use } \\
\text { adblocker? }\end{array}$} & Yes & 63 & $52,1 \%$ \\
\hline & No & 58 & $47,9 \%$ \\
\hline
\end{tabular}

The research utilizes SPSS software and Cronbach's Alpha Value to determine the reliability of its research results. To be classified as reliable, the values must be greater than 0,7 (Nunnally, 1978). Based on this reliability test, our results have passed the reliability test. A factor analysis is conducted to confirm each validity and each category's value, which must be 0,5 or greater. Based on the data in Table 2, each value's factor loading has passed the minimum mark of 0 Kaiser-Meyer-Olkin (KMO), which also indicates a good value 0,844 . It can also be observed that the alpha value is 0,917 on all five items, which pass the minimum value. Aside from Ad Irritation, the research does not implement a validity test for the intention of skipping ads, and due to its value of only having one variable and it is impossible to conduct a validity check on it.

To analyze the hypotheses, the Univariate Analysis of Variance Linear Model is used to examine each dependent variable's mean value. These dependent variables are ad irritation and intention of skipping ads. Based on Table 3, the results of the means are labeled as Content and Length. In order to answer our hypothesis, the significance (Sig) value must be below 0,005 . 
In Figure 2, based on the video ad's ad content, consumers are more irritated when they are exposed to long ads with either boring or entertaining ad content. However, they feel much more irritated when the ad content is boring. If both ad content and ad length are combined, as listed in Table 3 , ad content and ad length exceed the significance value, which means that our first hypothesis is not supported. This result contradicts Shareef et al. (2018), which find that entertaining ads can provide enjoyment and fun when being received. Seyedghorban et al. (2016) suggest that the consumers will tend to feel irritated towards the ads and will want to avoid the ad. Especially when a consumer is faced with an obstacle that prevents them from reaching their goal, perceives negative feelings towards ads, and rather sees it as an ad clutter.

The intention of skipping ads is also checked to answer the second hypothesis, as shown in Figure 3. Consumers tend to skip ads when it is boring. However, the intention of skipping ads is significantly lower when the ad is entertaining with a shorter length. This aligns with statement by Belanche et al. (2017), where an entertaining short online video ad will cause consumers to have a lower intention of skipping. This may stem from the habit and attitude that consumers have towards in-stream ads in general. When a consumer is irritated towards an ad, they will immediately decide to skip it by habit. Based on Table 3,

Table 2 Cronbach's Alpha Value and Factor Analysis

\begin{tabular}{lccc}
\hline \multicolumn{1}{c}{ Ads Irritation } & Factor Loading & KMO & Alpha \\
\hline The advertising is irritating & 0,820 & & \\
The advertising is fake/phony & 0,669 & & \\
The advertising is ridiculous & 0,898 & 0,844 & 0,917 \\
The advertising is stupid & 0,900 & & \\
The advertising is terrible & 0,904 & & \\
\hline
\end{tabular}

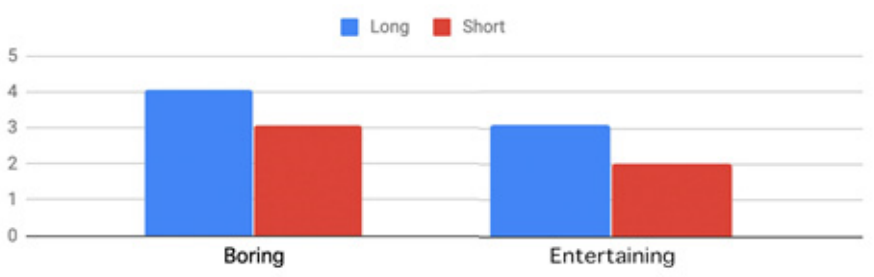

Figure 2 Mean for Ads Irritation

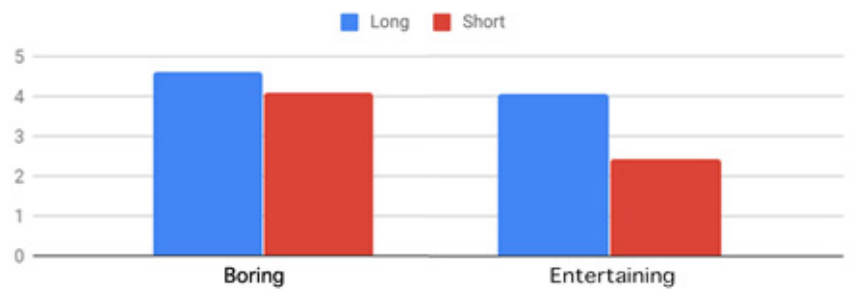

Figure 3 Mean for Intention to Skipping Ads

Table 3 Univariate Analysis Dependent Variable: Ads Irritation and Intention to Skipping Ads

\begin{tabular}{lcccccc}
\hline \multirow{1}{*}{ Data Source } & \multicolumn{3}{c}{ Ad Irritation } & \multicolumn{3}{c}{ Intention of Skipping Ad } \\
\cline { 2 - 7 } & Mean & F & Sig & Mean & F & Sig \\
\hline CONTENT & 31,212 & 34,525 & 0 & 38,533 & 36,028 & 0 \\
LENGTH & 32,865 & 36,354 & 0 & 34,133 & 31,914 & 0 \\
CONTENT * LENGTH & 0,33 & 0,37 & 0,848 & 9,633 & 9,007 & 0,003 \\
\hline
\end{tabular}

Sig value: $<0,005$ 
when both ad content and ad length are combined, the significance value is below the maximum. Thus, $\mathrm{H}_{2}$ is supported. Therefore, when tackling ad irritation and intention of skipping ads, advertisers should minimize the ad length to prevent ad avoidance. When the ad length is between 15 seconds and 30 seconds, our experiment shows that shorter length ads are less irritating. In contrast, when respondents are exposed to longer ads, they feel more irritated. Gesenhues (2014) suggests that the feeling of irritation felt by most consumers is a result of them having to wait and sit through for the duration of the in-stream commercials. This causes them to feel irritated, thus, more likely to skip or avoid these commercials by clicking the skip-ad button present (Cho, 2004; Edwards et al., 2002). As such, shorter ads with a high entertainment value will be more acceptable. On the other hand, when the ad length is deemed to be short, consumers show a lower intention of skipping. This may relate to our previous statement; if consumers are given a reason to wait, they would be less irritable, and when the entertainment content of a video ad is deemed adequate, consumers will show a lower intention of skipping the ads.

\section{CONCLUSIONS}

Based on the experiment results, it can be concluded that ad content insignificantly affects a consumer's ad irritation. Although several research show that ad irritation has been proven invalid (Murillo et al., 2016, Hamouda, 2018), it is proven that in the context of an online video ad, ad irritation has a negative influence on consumers' attitudes (more or less $28 \%$ ). Entertainment or enjoyment can be described as a feeling where consumers are invested and engaged in the stream of feelings from the characteristics and sensory cues that seek fun, which are arousing and enjoyable (Pee et al., 2019).

However, the research shows that the entertainment element is not a significant factor in online video ads. Based on our experiment, an ad's content has not taken a significant role to make people skip our video ads instead of seeing them. However, when video ads are entertaining and the length is short, people tend to watch the ads. Moreover, the respondents tend to skip the ad regardless of whether the ad is boring or entertaining. This aligns with previous research by Doodoo and Wen (2019), which suggested that consumers will avoid advertising whenever possible.

As such, the research would be able to contribute to the theoretical discussion of the impact of ad irritation and intention of skipping by examining two factors that are unique to online video ads: the ad content and ad length. As shown in the current research, the different combinations of these two attributes can reduce or increase the ad irritation and intention of skipping ads. After conducting the analysis, more companies have developed their marketing strategies even around online video ads. This includes ads in social media, video sharing or streaming websites, and more.

As for how a company approaches and places their product or brand in different platforms such as in online media, this may benefit the company compared to using a traditional advertising media. The reason is that it could integrated brands with its environment that enables consumers to have a high involvement with the brand and real-time constructive brand image (Vashisht \& Sreejesh, 2015). The research shows that online advertising is a useful tool to increase a customer's awareness about a particular product, service, brand, and the market. By using online video ads, as it can deliver interaction, information and is easily accessible. Dehghani et al. (2016) state that entertainment itself is an independent variable that could have a significant and positive influence on the perceived value of an ad for a customer. As seen in the previous discussion, consumers will still have a high intention of skipping ads due to the ad length whether it is entertaining or boring. This is supported by the previous research, which suggests longer ad video will keep or stall users away from their supposed goal for a set period, potentially making the consumers perception of the ad to be negative and see the ad as being intrusive, which then affects the consumer's attitude and intention towards the ad (McCoy, 2017). Furthermore, the intrusive nature of an ad can be seen as the ad interrupting the fluent flow of a media environment where such advertising appears in (Jankowski \& Lewandowska, 2017).

The research shows that advertisers should highlight the importance of having short ads as the main aspect of online video ads. This is to prevent the intention of skipping ads and ad irritation. Therefore, it could be challenging as an ad is supposed to not only be short but also deliver the message effectively. There are two limitations concerning this research and its experiment. First, as this experiment is done on a website that have been specifically prepared for it, there is a possibility that the consumers may react differently. Another limitation that this research is that the nature and characteristic of the ad will also be different, depending on the product or service advertised in online video ads. The research mainly focuses on food and beverage ads, so consumers' responses towards different products from different industries or services may also differ.

Several suggestions are provided for future research to tackle this issue. One of them is the use of ad during the experiment, as the ad's content may have affected the participants' intention of skipping ads. For future research, it is suggested the video ad is limited to only using two contents with different lengths to determine whether the same ad would have a different result (i.e., one soda ad with two different lengths). Additionally, there might be different results based on the type of ad (i.e., food \& beverage, products \& services). Thus, the result may vary depending on the product category. To be more specific, a consumer's 
level of involvement depends on the product category and may result in different results and behavior (Cruz, Leonhardt \& Pezzuti, 2017). A positive correlation might occur when a certain degree of consumer involvement correlates with the ad's effectiveness (Soliha \& Widyasari, 2018). More in-depth research may be needed to determine measurements to accurately examine the intention of skipping ads in online video ads. Factors such as consumers' habits and the chance that they may have seen the ad prior could influence their intention of skipping the ads. Future researchers may implement an eye-tracking method to see how long a consumer focuses on the ad before feeling irritated or show intentions of skipping. This may help examine the kind of entertainment value that is effective for consumers.

\section{REFERENCES}

Amarnath, D. D., \& Jaidev, U. P. (2020). Toward an integrated model of consumer reactance: A literature analysis. Management Review Quarterly, 1-50. https://doi.org/10.1007/s11301-020-00180-y.

Anderson, M. (2018, August). Understanding gen Z through the lens of YouTube. Think with Google. https:// www.thinkwithgoogle.com/advertising-channels/ video/gen-z-and-youtube/.

Belanche, D., Flavián, C., \& Pérez-Rueda, A. (2017). Understanding interactive online advertising: Congruence and product involvement in highly and lowly arousing, skippable video ads. Journal of Interactive Marketing, 37, 75-88. https://doi. org/10.1016/j.intmar.2016.06.004.

Benes, R. (2018, September 14). Advertisers get annoyed by ads too: Blocking ads appeals to people across industries. Insider Intelligence. https://www. emarketer.com/content/advertisers-get-annoyed-byads-too.

Campbell, C., Mattison Thompson, F., Grimm, P. E., \& Robson, K. (2017). Understanding Why Consumers Don't Skip Pre-Roll Video Ads. Journal of Advertising, 46(3), 411-423. https://doi.org/10.1080/ 00913367.2017 .1334249$.

Cho, C. H., \& Cheon, H. J. (2004). Why do people avoid advertising on the internet? Journal of Advertising, 33(4), 89-97. https://doi.org/10.1080/00913367.200 4.10639175.

Chun, H. H., Diehl, K., \& MacInnis, D. J. (2017). Savoring an upcoming experience affects ongoing and remembered consumption enjoyment. Journal of Marketing, 81(3), 96-110. https://doi.org/10.1509/ jm.15.0267.

Chung, Y. J., \& Kim, E. (2020). Predicting consumer avoidance of native advertising on social networking sites: A survey of Facebook users. Journal of Promotion Management, 27(1), 1-26. https://doi.or $\mathrm{g} / 10.1080 / 10496491.2020 .1809590$.

Cohen, L., Manion, L., \& Morrison, K. (2007). Research Methods in Education ( $6^{\text {th }}$ Ed.). London: Routledge.

Cruz, R. E., Leonhardt, J. M., \& Pezzuti, T. (2017). Second person pronouns enhance consumer involvement and brand attitude. Journal of Interactive Marketing, 39, 104-116. https://doi.org/10.1016/j. intmar.2017.05.001.

Dehghani, M., Niaki, M. K., Ramezani, I., \& Sali, R. (2016). Evaluating the influence of YouTube advertising for attraction of young customers. Computers in Human Behavior, 59, 165-172. https://doi.org/10.1016/j. chb.2016.01.037.

Dodoo, N. A., \& Wen, J. (2019). A path to mitigating SNS ad avoidance: Tailoring messages to individual personality traits. Journal of Interactive Advertising, 19(2), 116-132. https://doi.org/10.1080/15252019.2 019.1573159 .

Ducoffe, R. H. (1996). Advertising value and advertising on the web. Journal of Advertising Research, 36(5), 21 35. https://doi.org/10.1080/0144929X.2014.978380.

Edwards, S. M., Li, H., \& Lee, J. H. (2002). Forced exposure and psychological reactance: Antecedents and consequences of the perceived intrusiveness of pop-up ads. Journal of Advertising, 31(3), 83-95. https://doi.org/10.1080/00913367.2002.10673678.

Fleck, A. (2018, May 31). Marketers think the 6-second preroll spot is the best digital video ad format. AdWeek. https://www.adweek.com/tv-video/marketers-thinkthe-6-second-pre-roll-spot-is-the-best-digital-videoad-format/.

Gesenhues, A. (2014, June 20). Study: 56\% of viewers skip online video ads \& $46 \%$ say any ad over 15 -seconds is too long. Marketing Land. https://marketingland. com/study-56-viewers-skip-online-video-ads-46think-ad-15-seconds-long-88299.

Giao, H. N. K., \& Vuong, B. N. (2020). Vietnamese consumer attitudes towards smartphone advertising. Journal of Asian Finance, Economics and Business, 7(5), 195204. https://doi.org/10.13106/JAFEB.2020.VOL7. NO5.195.

Goodrich, K., Schiller, S. Z., \& Galletta, D. (2015). Consumer reactions to intrusiveness of onlinevideo advertisements do length, informativeness, and humor help (or hinder) marketing outcomes? Journal of Advertising Research, 55(1). https://doi. org/10.2501/JAR-55-1-037-050.

Hamouda, M. (2018). Understanding social media advertising effect on consumers' responses: An empirical investigation of tourism advertising on Facebook. Journal of Enterprise Information Management, 31(3), 426-445. https://doi. org/10.1108/JEIM-07-2017-0101.

Hardisty, D. J., \& Weber, E. U. (2020). Impatience and savoring vs. dread: Asymmetries in anticipation explain consumer time preferences for positive vs. negative events. Journal of Consumer Psychology. https://doi.org/10.1002/jcpy.1169.

Herhold, K. (2018). What consumers want in advertising. Clutch. https://clutch.co/agencies/ resources/whatconsumers-want-in-advertising.

Hoewe, J. (2017). Manipulation check. In The International Encyclopedia of Communication Research Methods, (pp. 1-5). https://doi.org/10.1002/9781118901731. iecrm0135. 
Huh, J., Delorme, D. E., \& Reid, L. N. (2015). Do consumers avoid watching over-the-counter drug advertisements? An analysis of cognitive and affective factors that prompt advertising avoidance. Journal of Advertising Research, 55(4), 401-415. https://doi.org/10.2501/JAR-2015-022.

Jankowski, J., \& Lewandowska, A. (2017). The negative impact of visual web advertising content on cognitive process: towards quantitative evaluation. International Journal of Human Computer Studies, 108, 41-49. https://doi.org/10.1016/j. ijhcs.2017.07.002.

Jeon, Y. A., Son, H., Chung, A. D., \& Drumwright, M. E. (2019). Temporal certainty and skippable in-stream commercials: Effects of ad length, timer, and skip-ad button on irritation and skipping behavior. Journal of Interactive Marketing, 47, 144-158. https://doi. org/10.1016/j.intmar.2019.02.005.

Jones, B. (2016). In video advertising, is longer stronger? Think with Google. www.thinkwithgoogle.com/ consumer-insights/unskippable-video-advertisingad-recall-brand-favorability/.

Jung, J., Shim, S. W., Jin, H. S., \& Khang, H. (2016). Factors affecting attitudes and behavioural intention towards social networking advertising: A case of facebook users in South Korea. International Journal of Advertising, 35(2), 248-265. https://doi.org/10.1080 /02650487.2015.1014777.

Kempers, R. T. (2020). How does YouTube and TV ads relevance, credibility and irritation influence consumers' purchasing intention? University of Twente, Enschede, Netherland.

Kim, N. Y. (2018). The effect of ad customization and ad variation on internet users' perceptions of forced multiple advertising exposures and attitudes. Journal of Interactive Advertising, 18(1), 15-27. https://doi. org/10.1080/15252019.2018.1460225.

Krizelman, T. (2019). Are YouTube video ads getting longer? Digital Content Next. https://digitalcontentnext.org/ blog/2019/04/09/are-youtube-video-ads-gettinglonger/.

Lee, J., \& Hong, I. B. (2016). Predicting positive user responses to social media advertising: The roles of emotional appeal, informativeness, and creativity. International Journal of Information Management, 36(3), 360-373. https://doi.org/10.1016/j. ijinfomgt.2016.01.001.

Li, H., \& Lo, H. Y. (2015). Do you recognize its brand? The effectiveness of online in-stream video advertisements. Journal of Advertising, 44(3), 208218. https://doi.org/10.1080/00913367.2014.95637 6.

Li, H., Edwards, S. M., \& Lee, J. H. (2002). Measuring the intrusiveness of advertisements: Scale development and validation. Journal of Advertising, 31(2), 37-47. https://doi.org/10.1080/00913367.2002.10673665

Li, W., \& Huang, Z. (2016). The research of influence factors of online behavioral advertising avoidance. American Journal of Industrial and Business Management, 6(9), 947-957. https://doi.org/10.4236/ ajibm.2016.69092.
Mahatmavidya, P. A., \& Yasa, N. N. K. (2020). Advertising value of Instagram stories and the effect on millennial's attitude. Russian Journal of Agricultural and Socio-Economic Sciences, 3(99), 29-39. https:// doi.org/10.18551/rjoas.2020-03.04.

Manatt, K. (2017). Turbo charging your skippable preroll campaign. MAGNA Global. https://www. magnaglobal.com/wp-content/uploads/2017/02/ Magna.IPGlab_Turbocharging-Your-Skippable-PreRoll-Campaign_external.pdf.

McCoy, S., Everard, A., Galletta, D. F., \& Moody, G. D. (2017). Here we go again! The impact of website ad repetition on recall, intrusiveness, attitudes, and site revisit intentions. Information and Management, 54(1), 14-24. $\quad$ https://doi.org/10.1016/j. im.2016.03.005.

MRC cross-media audience measurement standards (phase I video). (2020, September). Media Rating Council. http://mediaratingcouncil.org/MRC\%20 Cross-Media $\% 20$ Audience $\% 20$ Measurement $\% 20$ Standards\%20(Phase\%20I\%20Video)\%20Final.pdf.

Murillo, E. (2017). Attitudes toward mobile search ads: A study among Mexican millennials. Journal of Research in Interactive Marketing, 11(1), 91-108. https://doi.org/10.1108/JRIM-06-2016-0061.

Murillo, E., Merino, M., \& Núñez,A. (2016). The advertising value of Twitter ads: A study among Mexican millennials. Review of Business Management, 18(61), 436-456. https://doi.org/10.7819/rbgn. v18i61.2471.

Núñez-Barriopedro, E., Klusek, K. G., \& Tobar-Pesántez, L. (2019). The effectiveness of humor in advertising: Analysis from an international scope. Academy of Strategic Management Journal, 18(4). https:// www.scopus.com/record/display.uri?eid=2-s2.085078911863 \&origin $=$ inward\&txGid $=566 \mathrm{a} 094850$ 242bee0ef90176fd54742a.

Nunnally, J. C. (1978). Psychometric Theory (2 ${ }^{\text {nd }}$ Ed.). New York: McGraw-Hill.

Park, L. M., \& Han, S. (2019). The effectiveness of the process of mobile video advertising - Focused on the perceived intrusiveness and attitude toward advertising. International Journal of Innovative Technology and Exploring Engineering, 8(8), 264269.

Pashkevich, M., Dorai-Raj, S., Kellar, M., \& Dan, Z. (2012). Empowering online advertisements by empowering viewers with the right to choose: The relative effectiveness of skippable video advertisements on YouTube. Journal of Advertising Research, 52(4), 451-457. https://doi.org/10.2501/JAR-52-4-451457.

Pee, L. G., Jiang, J. J., \& Klein, G. (2019). E-store loyalty: Longitudinal comparison of website usefulness and satisfaction. International Journal of Market Research, 61(2), 178-194. https://doi. org/10.1177/1470785317752045.

Petrovici, D. A., Marinova, S. T., \& Marinov, M. A. (2017). Perceived advertising intrusiveness and avoidance in emerging economies: The case of China. In M. A. Marinov (Eds.), Research Handbook of Marketing 
in Emerging Economies (pp. 125-145). https://doi. org/10.4337/9781784713171.

Puwandi, P. H., Tiara, G., \& Brasali, N. (2019). The factors affecting consumer response towards online video advertisement: YouTube as a platform. International Journal of Multicultural and Multireligious Understanding (IJMMU), 7(2), 375-390. http:// dx.doi.org/10.18415/ijmmu.v7i2.1396.

Redondo, I., \& Aznar, G. (2018). To use or not to use ad blockers? The roles of knowledge of ad blockers and attitude toward online advertising. Telematics and Informatics, 35(6), 1607-1616. https://doi. org/10.1016/j.tele.2018.04.008.

Seyedghorban, Z., Tahernejad, H., \& Matanda, M. J. (2016). Reinquiry into advertising avoidance on the internet: A conceptual replication and extension. Journal of Advertising, 45(1), 120-129. https://doi.org/10.1080 /00913367.2015.1085819.

Share of consumers who felt annoyed by YouTube advertising videos in the United States as of May 2017 (2019). Statista. https://www.statista.com/ statistics/718488/us-consumer-opinion-youtubevideo-advertising/.

Shareef, M. A., Mukerji, B., Alryalat, M. A. A., Wright, A., \& Dwivedi, Y. K. (2018). Advertisements on Facebook: Identifying the persuasive elements in the development of positive attitudes in consumers. Journal of Retailing and Consumer Services, 43, 258-268. https://doi.org/10.1016/j. jretconser.2018.04.006.

Shehu, E., Bijmolt, T. H. A., \& Clement, M. (2016). Effects of Likeability Dynamics on Consumers' Intention to Share Online Video Advertisements. Journal of Interactive Marketing, 35, 27-43. https://doi. org/10.1016/j.intmar.2016.01.001.

Soliha, E., \& Widyasari, S. (2018). Message framing and source credibility in product advertisements with high consumer involvement. European Research Studies Journal, 21(Special Issue 3), 413-422. https://doi.org/10.35808/ersj/1392.

Song, X., Xu, B., \& Jiang, Y.-G. (2020). Predicting Content Similarity via Multimodal Modeling for Video-InVideo Advertising. IEEE Transactions on Circuits and Systems for Video Technology, 8215(c), 1-1. https://doi.org/10.1109/tcsvt.2020.2979928.

Tsai, W. H. S., \& Men, L. R. (2017). Consumer engagement with brands on social network sites: A cross-cultural comparison of China and the USA. Journal of Marketing Communications, 23(1), 2-21. https://doi. org/10.1080/13527266.2014.942678.
Vashisht, D., \& Sreejesh, S. (2015). Effects of brand placement strength, prior game playing experience and game involvement on brand recall in advergames. Journal of Indian Business Research, 7(3), 292-312. https://doi.org/10.1108/JIBR-11-2014-0082.

Vohra, A., \& Bhardwaj, N. (2019). From active participation to engagement in online communities: Analysing the mediating role of trust and commitment. Journal of Marketing Communications, 25(1), 89-114. https:// doi.org/10.1080/13527266.2017.1393768.

Warren, C., Barsky, A., \& Mcgraw, A. P. (2018). Humor, comedy, and consumer behavior. Journal of Consumer Research, 45(3), 529-552. https://doi. org/10.1093/jcr/ucy015.

Wasserman, T. (2020, August 10). The 30-second TV ad is history: Now what? Forbes. https://www.forbes. com/sites/toddwasserman/2020/08/10/the-30second-tv-ad-is-history-now-what/\#2a833b142b1e.

Why you should be making 6-second video ads in 2018. (2017, October 10). Shutterstock. https://www. shutterstock.com/blog/6-second-video-ads-2018strategy.

Willner, M. (2018, September 6). New data on why people hate ads: Too many, too intrusive, too creepy. VIEO Design. https://www.vieodesign.com/blog/newdata-why-people-hate-ads.

Yang, K.-C., Huang, C.-H., Yang, C., \& Yang, S. Y. (2018). Consumer attitudes toward online video advertisement: Youtube as a platform. Kybernetes, 46(5), 840-853. https://doi. org/10.1108/K-03-2016-0038.

Youn, S., \& Kim, S. (2019). Understanding ad avoidance on Facebook: Antecedents and outcomes of psychological reactance. Computers in Human Behavior, 98, 232-244. https://doi.org/10.1016/j. chb.2019.04.025.

Youn, S., \& Shin, W. (2019). Teens' responses to Facebook newsfeed advertising: The effects of cognitive appraisal and social influence on privacy concerns and coping strategies. Telematics and Informatics, 38, 30-45. https://doi.org/10.1016/j.tele.2019.02.001.

Zhang, E. M. (2016). From Online Motivations to Ad Clicks and to Behavioral Intentions: An Empirical Study of Consumer Response to Social Media Advertising. Psychology \& Marketing, 33(3), 155-164. https:// doi.org/10.1002/mar.

Zhou, L., \& Xue, F. (2019). In-feed native advertising on news websites: Effects of advertising format, website reputation, and product involvement. Journal of Internet Commerce, 18(3), 270-290. https://doi.org /10.1080/15332861.2019.1586361. 